\title{
EFEKTIFITAS HUKUMAN DISIPLIN BAGI PEGAWAI NEGERI SIPIL YANG MELANGGAR DISIPLIN DI DINAS PENDIDIKAN KABUPATEN KEDIRI
}

\author{
Sumar Susantinah \\ Bagian Hukum Setda Kabupaten Kediri \\ Email: mizanjurnalilmuhukum@gmail.com
}

\begin{abstract}
ABSTRAK
Aparatur Sipil Negara (selanjutnya disingkat ASN) sebagai unsur utama sumber daya manusia aparatur negara mempunyai peranan yang menentukan terhadap keberhasilan penyelenggaraan pemerintahan dan pembangunan.

Efektivitas adalah tingkat keberhasilan dalam mencapai tujuan atau sasaran. Efektifitas ini sesungguhnya merupakan suatu konsep yang lebih luas mencakup berbagai faktor didalam maupun diluar diri seorang, efektivitas hukum maka kita pertama-tama haru dapat mengukur sejauh mana aturan hukum itu ditaati atau tidak ditaati, Derajat dari efektivitas hukum menurut Soerjono Soekanto, ditentukan oleh taraf kepatuhan masyarakat terhadap hukum, termasuk para penegak hukumnya, sehingga dikenal asumsi bahwa, "taraf kepatuhan yang tinggi adalah indikator suatu berfungsinya suatu sistem hukum

Permasalahan yang dibahas dari penelitian ini adalah sebagai berikut : 1. Bagaimana efektifitas hukuman disiplin bagi PNS yang melanggar disiplin di Dinas Pendidikan Kabupaten Kediri? 2. Faktor-faktor apa saja yang mempengaruhi efektifitas hukuman disiplin di Dinas Pendidikan Kabupaten Kediri? 3. Bagaimana solusi dari Dinas Pendidikan untuk meningkatkan Disiplin PNS di Lingkungan Dinas Pendidikan? yang digunakan dalam penelitian ini adalah pendekatan yuridis normatif dan yuridis empiris. Sumber-sumber penelitian hukum dalam penulisan tesis ini dapat dibedakan menjadi penelitian hukum yang deskripsi analisis, yaitu menggambarkan peraturan perundang-undangan yang berlaku dikaitkan dengan teori-teori hukum dan praktek pelaksanaan hukum positif yang menyangkut permasalahan yang di hadapi oleh penulis.

Disiplin adalah prosedur yang mengoreksi atau menghukum bawahan karena melanggar peraturan atau prosedur, Disiplin kerja adalah kemampuan kerja seseorang untuk secara teratur, tekun,terus-menerus dan bekerja sesuai dengan aturan-aturan yang berlaku dengantidak melanggar aturan-aturan yang sudah ditetapkan.

Kata Kunci : Aparatur Sipil Negara, Efektifitas Hukum, Disiplin.
\end{abstract}

\section{ABSTRACT}

REGENCY State Civil Apparatus (bereinafter abbreviated as ASN) as the main element of human resources of the state apparatus has a decisive role on the success of governance and development.

Effectiveness is the level of success in achieving goals or objectives. This effectiveness is actually a broader concept that includes a variety of factors within and outside of a person, the effectiveness of the law then we must first be able to measure the extent to which the rule of law is obeyed or not obeyed, The degree of legal effectiveness according Soerjono Soekanto, determined by the level of compliance society to law, including its law enforcers, so it is known the assumption that, "the high level of compliance is an indicator of the functioning of a legal system.

Problems discussed from this research are as follows: 1. How is the effectiveness of disciplinary punishment for civil servants who violate the Kediri District Education Office? 2. What factors affect the effectiveness of disciplinary punishment in Kediri District Education Office? 3. How is the solution of the Education Office to improve the Civil Service Discipline in Education Department Environment? which is used in this research is juridical normative and juridical empirical approach. The sources of legal research in the writing of this thesis can be distinguished into a legal research that description of the analysis, which describes the applicable legislation is associated with legal theories and practice of the implementation of positive law concerning the problems faced by the author.

Discipline is a procedure that corrects or punishes subordinates for violating rules or procedures. The discipline of work is the ability of one's work to regularly, diligently, constantly and to work in accordance with the rules applicable by not violating the rules that have been determined. 
Keywords: State civil apparatus, Legal effectiveness, Discipline.

\section{A. PENDAHULUAN}

Aparatur Sipil Negara (selanjutnya disingkat ASN) sebagai unsur utama sumber daya manusia aparatur negara mempunyai peranan yang menentukan terhadap keberhasilan penyelenggaraan pemerintahan dan pembangunan.bahwa kelancaran pelaksanaan pemerintahan dan pembangunan nasional terutama tergantung dari kesempurnaan aparatur negara. Sebelum dibahas lebih lanjut, perlu diketahui pengertian dari Aparatur Sipil Negara sebagaimana yang tercantum dalam Pasal 1 angka 1 dan angka 2 Undang-Undang Nomor 5 Tahun 2014 selanjutnya di singkat ASN, yaitu sebagai berikut:

1. Aparatur Sipil Negara yang selanjutnya disingkat ASN adalah profesi bagi pegawai negeri sipil dan pegawai pemerintah dengan perjanjian kerja yang bekerja pada instansi pemerintah.

2. Pegawai Aparatur Sipil Negara yang selanjutnya disebut Pegawai ASN adalah pegawai negeri sipil dan pegawai pemerintah dengan perjanjian kerja yang diangkat oleh pejabat pembina kepegawaian dan diserahi tugas dalam suatu jabatan pemerintahan atau diserahi tugas negara lainnya dan digaji berdasarkan peraturan perundangundangan.

Berdasarkan ketentuan di atas bahwa ASN menjadi tumpuan dalam pelaksanaan pemerintahan sesuai dengan tugas dan fungsi masing-masing, namun dalam pelaksanaan tugas dan fungsinya, terdapat sejumlah permasalahan yang dihadapi oleh birokrasi Indonesia berkenaan dengan Sumber Daya Manusia (selanjutnya disingkat SDM).

Sesuai dengan tuntutan reformasi dalam era keterbukaan, profesionalisme kualitas pelayanan terutama pejabat pelaksana kebijakan yaitu Kepala Dinas Pendidikan harus ditingkatkan, hal tersebut sangat erat hubungannya dengan sumber daya manusia yang ada di UPTD dan lembaga-lembaga pendidikan secara keseluruhan, namun pada kenyataannya dalam setiap dinas atau instansi pasti masih ada saja pegawai yang kurang disiplin dan kurang optimal dalam melaksanakan tugas-tugas kedinasan bahkan belum memahami peraturan perundangundangan yang menjadi pedoman kerja atau panutan

Berat ringannya sanksi hukuman yang diterapkan akan mempengaruhi baik/buruknya kedisiplinan pegawai. Sanksi hukuman harus dipertimbangkan secara logis, masuk akal dan diinformasikan secara jelas kepada semua pegawai. Sanksi hukuman diberikan dengan tujuan mendidik pegawai yang berperilaku indisipliner untuk tidak mengulangi lagi perilakunya tersebut.

\section{Tujuan Penelitian}

Berdasarkan pada pokok bahasan di atas maka tujuan dari penelitian ini adalah:

1. Untuk mengetahui efektifitas hukuman disiplin bagi PNS yang melanggar disiplin di Dinas Pendidikan Kabupaten Kediri.

2. Untuk mengetahui faktor-faktor yang mempengaruhi efektifitas hukuman disiplin di Dinas Pendidikan Kabupaten Kediri.

3. Untuk mengetahui solusi Dinas Pendidikan untuk meningkatkan Disiplin PNS di Lingkungan Dinas Pendidikan.

\section{Manfaat Penelitian}

Kegunaan penelitian ini terdiri dari kegunaan teoretis dan kegunaan praktissebagai berikut:

1. Kegunaan Teoretis

Hasil penelitian ini diharapkan dapat mengembangkan ilmu hukum, khususnya dalam bidang hukum administrasi Negara tentang hukuman disiplin terhadap Pegawa Negeri Sipil.

2. Kegunaan Praktis

Hasil penelitian ini diharapkan dapat menjadi sebuah masukan berharga sebagai masukan atau menambah pengetahuan terkait dengan kedisiplinan serta menegakkan kedisiplinan aparatur sipil negara di lingkungan kerja.

\section{B. METODE PENELITIAN}

Metode pendekatan yang digunakan dalam penelitian ini adalah pendekatan yuridis empiris. Pendekatan yuridis empiris digunakan dengan pertimbangan bahwa penelitian ini bertujuan untuk membahas 
dan mengkaji berbagai peraturan yang berkaitan dengan peraturan disiplin PNS dan bagaimana peraturan tersebut diimplementasikan di Dinas Pendidikan Kabupaten Kediri.

\section{Sumber dan Jenis Data}

Penelitian ini termasuk dalam penelitian hukum yang deskripsi analisis, yaitu menggambarkan peraturan perundangundangan yang berlaku dikaitkan dengan teori-teori hukum dan praktek pelaksanaan hukum positif yang menyangkut permasalahan diatas. Deskriptif karena dalam penelitian ini diharapkan akan diperoleh gambaran yang menyeluruh dan sistematis tentang pemberian sanksi administratif disiplin Aparatur Sipil Negara.

Untuk mendapatkan data yang objektif, maka dalam penelitian ini penulis menggunakan :

a. Data Primer

Data primer adalah data yang diperoleh langsung dari hasil penelitian dilapangan dengan menggunakan metode wawancara dengan responden dari Dinas Pendidikan yang terlibat langsung dalam menanggani arsip-arsip yang berhubungan dengan penelitian untuk memperoleh data yang sesuai dengan kenyataan.

b. Data Sekunder

Data sekunder merupakan sumber data penelitian yang diperoleh dari pustaka berupa peraturan perundang-undangan yang ada maupun melalui pendapat para sarjana atau ahli hukum. Penelitian Kepustakaan adalah penelitian yang dilakukan dengan mempelajari bahanbahan hukum yang berkaitan dengan masalah yang akan diteliti untuk memperoleh data sekunder yang terdiri dari:

1) Bahan Hukum Primer yaitu bahan hukum yang mengikat,terdiri dari Undang-undang, Peratura-Pemerintah

2) Bahan hukum sekunder yaitu bahan hukum yang menjelaskan bahan hukum primer, terdiri dari berbagai bahan kepustakaan dan makalahmakalah yang membahas mengenai pengaturan kepegawaian dan kinerja Pegawai Negeri Sipil.

Metode Pengumpulan dan Pengolahan Data
Pengumpulan data mempergunakan langkah-langkah sebagai berikut :

A. Pengumpulan Data

1. Studi kepustakaan (Library Research)

2. Studi lapangan (Field Research)

Studi lapangan merupakan penelitian yang dilakukan dengan cara wawancara yaitu sebagai usaha mengumpulkan data dengan mengajukan pertanyaan secara lisan. Responden yang diwawancarai adalah Kepala Dinas Pendidikan Kabupaten Kediri.

a. Pengolahan Data

Setelah data terkumpul, maka data diproses melalui pengelolaan data dengan langkahlangkah sebagai berikut:

1. Identifikasi data, yaitu mencari data yang diperoleh untuk disesuaikan dengan pembahasan yang akan dilakukan yaitu dengan menelaah peraturan, buku atau artikel yang berkaitan dengan judul yang akan dibahas.

2. Klasifikasi data, yaitu hasil identifikasi data yang selanjutnya diklasifikasikan atau dikelompokan sehingga diperoleh data yang benar-benar objektif.

3. Sistematisasi data, yaitu menyusun data menurut sistematika yang telah ditetapkan dalam penelitian sehingga memudahkan peneliti dalam menginterprestasikan data.

Analisis Data

Analisis data adalah proses penyederhanaan data ke dalam bentuk yang lebih mudah dibaca dan diinterpretasikan. Analisis data dalam penelitian berlangsung bersamaan dengan proses pengumpulan data.

Metode analisis yang digunakan adalah kualitatif normatif berdasarkan buku-buku literatur dan peraturan yang berhubungan dengan sanksi administrasi dan disiplin Pegawai Negeri Sipil serta bahan-bahan lain yang terkait. Data yang telah dianalisis ini kemudian menjadi dasar dalam penarikan kesimpulan.

\section{HASIL DAN PEMBAHASAN}

Gambaran Umum Lokasi Penelitian

Dinas Pendidikan Kabupaten Kediri

Penyelenggaraan urusan pemerintahan oleh Pemerintah Daerah dan Dewan Perwakilan Rakyat sesuai dengan Undang- 
undang Nomor 23 Tahun 2014 tentang Pemerintahan Daerah dilaksanakan menurut asas otonomi dan tugas pembantuan dengan prinsip otonomi seluas-luasnya dalam system dan prinsip Negara Kesatuan Republik Indonesia sebagaimana dimaksud dalam Undang-undang Dasar Negara Republik Indonesia Tahun 1945. Urusan pemerintahan yang diselenggarakan pemerintah daerah untuk melindungi, melayani, memberdayakan dan menyejahterakan masyarakat. Pelaksana urusan Pemerintahan Daerah adalah SKPD yang dibentuk sesuai dengan Peraturan Daerah Kabupaten Kediri Nomor 5 Tahun 2016 tentang Pembentukan dan Susunan Perangkat Daerah Kabupaten Kediri.

Dengan berlakunya Undang-undang Nomor 23 Tahun 2014 tentang Pemerintahan Daerah sebagaimana telah diubah dengan Undang-undang Nomor 9 Tahun 2015, maka sejak tanggal 1 Januari 2017 urusan Pendidikan Menengah (SMA/SMK/MA) dan Pendidikan Luar Biasa telah menjadi kewenangan Pemerintah Provinsi Jawa Timur, sehingga focus pembangunan bidang pendidikan, diarahkan pada pendidikan dasar 9 tahun yang meliputi: 1) Pendidikan moral/budi pekerti, untuk membangun watak dan kepribadian bangsa yang kokoh, cinta perdamaian, sadar hukum, anti korupsi, cinta tanah air sebagai landasan untuk membentuk sumber daya manusia yang utuh; dan 2) Membebaskan biaya pendidikan pada tingkat pendidikan tertentu dan/atau menekan biaya pendidikan pada tingkat yang terjangkau oleh masyarakat serta memberikan kontribusi sesuai dengan kemampuan keuangan daerah.

Efektifitas Hukuman Bagi PNS yang Melanggar Disiplin di Dinas Pendidikan Kabupaten Kediri

Peraturan Pemerintah Nomor 53 Tahun 2010, Pasal 1 angka 3 menyebutkan bahwa pelanggaran disiplin adalah setiap ucapan, tulisan, atau perbuatan PNS yang tidak menaati kewajiban dan atau melanggar larangan ketentuan disiplin PNS, baik yang dilakukan di dalam maupun diluar jam kerja.

Penjatuhan hukuman disiplin ditetapkan dengan keputusan pejabat yang berwenang menghukum. Keputusan tersebut disampaikan secara tertutup oleh pejabat yang berwenang menghukum atau pejabat lain yang ditunjuk kepada PNS yang bersangkutan serta tembusannya disampaikan kepada pejabat instansi terkait. Penyampaian keputusan hukuman disiplin dilakukan paling lambat 14 hari kerja sejak keputusan ditetapkan.

PNS tersebut tidak setuju dengan keputusan pejabat terkait pelanggaran disiplin PNS, maka dapat dilakukan upaya administratif, yang terdiri dari:

a. keberatan; dan

b. banding administratif

Ada sejumlah permasalahan yang dihadapi oleh Dinas Pendidikan Kabupaten Kediri, permasalahan tersebut antara lain besarnya jumlah PNS yang melakukan pelanggaran disiplin sebagai aparatur sipil Negara maupun social kemasyarakatan. Sebuah kenyataan yang terjadi dalam kehidupan sehari-hari tentang birokrasi dinyatakan bahwa mereka, Pegawai Negeri Sipil Daerah kerja santai, pulang cepat dan mempersulit urusan serta identik dengan sebuah adagium "mengapa harus dipermudah apabila dapat dipersulit". Gambaran umum tersebut sudah sedemikian melekatnya dalam benak publik masyarakat sehingga banyak kalangan yang berasumsi bahwa perbedaan antara dunia preman dengan birokrasi hanya terletak pada pakaian dinas saja.

Begitu parahnya pandangan masyarakat mengenai Pegawai Negeri Sipil Daerah. Pemerintah Daerah Kabupaten Kediri melaporkan, terdapat 44\% Pegawai Negeri Sipil Dinas Pendidikan Kabupaten Kediridari yang berkinerja buruk. Salah satu indikasi rendahnya kualitas PNS Dinas Pendidikan tersebut adalah adanya pelanggaran disiplin yang banyak dilakukan.

Teori efektifitas hukum menurut Soerjono Soekanto adalah bahwa efektif atau tidaknya suatu hukum ditentukan oleh 5 (lima) faktor, yaitu:

a. Faktor hukumnya sendiri (undangundang);

b. Faktor penegak hukum, yakni pihakpihak yang membentuk maupun menerapkan hokum;

c. Faktor sarana atau fasilitas yang mendukung penegakan hukum;

d. Faktor masyarakat, yakni lingkungan dimana hukum tersebut berlaku atau diterapkan; 
e. Faktor kebudayaan, yakni sebagai hasil karya, cipta dan rasa yang didasarkan pada karsa.

Kelima faktor tersebut saling berkaitan satu sama lainnya, oleh karena merupakan esensi penegakan hukum, serta juga merupakan tolok ukur daripada efektifitas penegakan hokum.

\section{Faktor yang Menjadikan Kendala Hukuman Disiplin bagi PNS menjadi efektif}

Mekanisme yang telah diterapkan melalui Peraturan Pemerintah diatas seharusnya kinerja Pegawai Negeri Sipil dapat menunjukan perbaikan kearah yang positif bahkan adanya grafik yang tajam. Sampai dengan saat ini perubahan-perubahan itu tidak menampakkan grafik yang diinginkan meskipun dilihat dari penegakan hukuman yang telah ada tidak menampikkan bahwa adanya peranan dari Peraturan Pemerintah Nomor 53 Tahun 2010 tentang Disiplin Pegawai Negeri Sipil.

Peraturan Perundang-undangan tentang Kepegawaian menempatkan posisi pada jenis peraturan hukum publik. Dimana hukum kebijaksanaan publik merupakan variable yang memiliki keterkaitan erat sehingga telaah tentang tentang kebijaksanaan pemerintah semakin dibutuhkan untuk dapat dirasakan berseiring dengan semakin meluasnya persolan terutamanya tentang birokrasi Pegawai Negeri sipil. Melalui peraturan Perundang-undangan tentang kepegawaian pemerintah senyatanya dapat dikatakan melaksanakan pembangunan dikarenakan dengan disiplin Pegawai Negeri Sipil dalam melaksanakan tugas Pokok dan Fungsinya secara baik maka roda pembangunan yang didukung aparatur Pegawai Negeri Sipil dapat berjalan secara optimal.

\section{Solusi Meningkatkan Disiplin PNS di Lingkungan Dinas Pendidikan Kabupaten Kediri}

Salah satu alternatif sebagai upaya yang perlu ditempuh dalam rangka mengurangi jumlah pelanggaran disiplin antara lain adalah, Pertama,melakukan sosialisasi untuk memberikan penyegaran tentang peraturanperaturan yang berkaitan dengan disiplin PNS diantaranya PP No. 53 Tahun 2010 tentang Peraturan disiplin, PP No. 32 tahun 1979 tentang Pemberhentian PNS, PP No.45 Tahun 1990 sebagai penganti PP No.10
Tahun 1983 tentang Izin perkawinan dan penceraian PNS. Kegiatan sosialisasi bisa melalui pendidikan dan latihan (Diklat), Bimbingan Teknis (Bintek) serta bentuk program kerja lainnya yang bertujuan memberikan pemahaman dan mengaplikasikan peraturan yang berkaitan disiplin PNS.

Kedua, Memberikan sanksi/tindakan secara tegas bilamana seorang PNS terbukti melakukan pelanggaran disiplin yang tujuan untuk memberikan efek jera dan shock terapi agar PNS yang lain tidak meniru atau melakukannya.dan juga agar tidak melakukan pelanggaran yang hukumannya lebih berat lagi.

Ketiga, setidaknya setiap Satuan Kerja Perangkat Daerah (SKPD) merasa bertanggungjawab mengawasi dan melakukan pembinaan secara dini dilingkungan kerjanya mengenai kedisiplinan. Suatu misal bilamana terdapat stafnya yang melanggar tindakan disiplin, setidaknya segera melakukan pendekatan untuk menanyakan permasalahan yang dihadapi dan permasalahan yang menyebabkan yang bersangkutan tidak disiplin.

Keempat, setidaknya setiap PNS instropeksi dan merasa mensyukuri bahwa tidak semua orang bisa lolos dan berkesempatan menjadi PNS. Coba kita lihat saja setiap penerimaan CPNS dari tahun ke tahun jumlah pelamar yang ingin mengabdi menjadi PNS sampai dengan ribua orang. Tetapi sekarang yang telah menjadi PNS malah banyak yang melakukan pelanggaran disiplin tidak mentaati peraturan yang ada. Bila sudah menjadi PNS setidaknya harus konsekuen dan siap mental untuk mentaati peraturan yang ada. Selain itu menurut kebanyakan orang, PNS merupakan profesi yang sangat didambakan setiap orang dengan alasan antara lainmempunyai status yang jelas, terjaminnya ekonomi keluarga karena berpenghasilan tetap, tidak mungkin di berhentikan atau Pemutusan Hubungan Kerja (PHK), mempunyai jaminan hari tua (pensiun) dan jam kerjanya teratur.

\section{KESIMPULAN}

Berdasarkan hasil pemaparan pada bab-bab sebelumnya, dapat ditarik beberapa kesimpuilan sebagai berikut: 
1. Efektifitas penerapan hukuman disiplin terhadap Pegawai Negeri Sipil di lingkup Dinas Pendidikan Kabupaten Kediri telah berlaku secara adil sesuai tingkat pelanggaran yang dilakukan oleh aparatur sipil negara, yaitu sebagai 14 orang pegawai negeri sipil pada tahun 2016 dan 6 orang pegawai negeri sipil pada tahun 2017.

2. Faktor-faktor yang mempengaruhi efektifitas hukuman disiplin di Dinas Pendidikan Kabupaten Kediri, yaitu: a) Kurang tegasnya Sanksi yang diberikan oleh Pejabat yang berwenang. Pejabat yang berwenang harus memberikan sanksi/tindakan secara tegas bilamana seorang PNS terbukti melakukan pelanggaran disiplin. 2) Lunturnya Kedisiplinan Pegawai Negeri Sipil.

3. Solusi Dinas Pendidikan Kabupaten Kediri dalam menghadapi kendala yang dihadapi Dinas Pendidikan Kabupaten Kediri dalam peningkatan disiplin pegawai negeri sipil antara lain: 1) melakukan sosialisasi untuk memberikan penyegaran tentang peraturan-peraturan yang berkaitan dengan disiplin PNS; 2) Memberikan sanksi/tindakan secara tegas bilamana seorang PNS terbukti melakukan pelanggaran disiplin; 3) Satuan Kerja Perangkat Daerah (SKPD) harus bertanggungjawab mengawasi dan melakukan pembinaan secara dini dilingkungan kerjanya mengenai kedisiplinan; 4) setidaknya setiap PNS instropeksi dan merasa mensyukuri bahwa tidak semua orang bisa lolos dan berkesempatan menjadi PNS.

\section{E. DAFTAR PUSTAKA}

Buku :

Bungin, Burhan. 2001. Metodologi Penelitian Kualitatif, Aktualisasi Metodologiske Arb Ragam Varian Kontemporer. Jakarta, PT. Raja Grafindo Persada.

Gomes, Faustino Cardoso. 1995. Manajemen Sumber Daya Manusia. Yogyakarta,Penerbit Andi.

Gulo, W. 2002. Metodologi Penelitian. Jakarta, Gramedia Widiasarana Indonesia.

Hanitijo Ronny, 19909, Metodologi Penelitian Hukum,Bandung: Balai Pustaka

Hadiperwono. 1982. Tata Personalia. Bandung, Penerbit Djambatan.
Harini, Retno Sri. Tata Cara Pemeriksaan dan BAP, Disampaikan PadaOrientasi Peningkatan Kemampuan Tenaga Teknis AdministrasiKepegawaian Dari 4 (Empat) Lingkungan Peradilan Tingkat BandingDan Tingkeat Pertama Kelas I.A Selurub Indonesia Tabun Anggaran 2007.Cilegon, 3-6 Desember 2007.

Indriantoro, Nur dan Bambang Supomo. 2002. Metodologi Penelitian BisnisUntuk Akuntansi dan Manajemen. Yogyakarta, BPFE.

Lembaga Administrasi Negara RI. 1984. Manajemen Dalam Pemerintahan.Jakarta, Lembaga Administrasi Negara-Republik Indonesia dan YayasanPenerbit Administrasi.

M. Situmorang,Victor dan Jusuf Juhir. 1994. Aspek. Hukum Pengawasan Melekatdi lingkungan Aparatur Pemerintah. Jakarta, PT. Rineka Cipta.

Muchsan. 1994. Beberapa Catatan Tentang Hukum Administrasi Negara danPeradilan Administrasi Negara di Indonesia. Yogyakarta, Liberty.

Prijodarminto, Soegeng. 1994. Disiplin Kiat Meniju Sukses. Bandung, PradnyaParamita.

Sinungun, Muchdarsyah. 2000. Productivitas, Apa dan Bagaimana. Jakarta, Bumi Aksara.

Soekanto, Soerjono dan Sri Mamuji. 1986. Penelitian Hukum Normatif, SuatuTinjanan Singkat. Jakarta, Rajawali.

Soekanto, Soerjono. 2007. Pengantar Penelitian Hukum. Jakarta, Penerbit Universitas Indonesia.

Soemitro, Ronny Hanitijo. 1988. Metode Penelitian Hukum dan Jurimetri.

Jakarta, Ghalia Indonesia.

Sulistiyani, Ambar Teguh. 2004. Memahami Good Governance Dalam Perspektif Sumber Daya Manusia. Yogyakarta, Penerbit Gaya Media.

Supriyadi, Gering dan Trio Guno. 2006. Budaya Kerja Organisasi Pemerintah.Jakarta, Lembaga Administrasi Negara.

Teguh Sulistiyani Ambar, 2004, Memahami Good Governance Dalam Perspektif Sumber Daya Manusia, Yogyakarta: Penerbit Gaya Media 
Unaradjan, Dolet. 2003. Manajemen Disiplin. Jakarta, PT. Gramedia Widia sarana Indonesia.

Wicaksono, Kristian Widya. 2006. Administrasi dan Birokrasi Pemerintah.Yogyakarta, Penerbit Graha Ilmu.

Perundang-undangan:

Undang-undang Nomor 5 Tahun 2014 tentang Aparatur Sipil Negara.

Undang-Undang Nomor 43 Tahun 1999 tentang Pokok-Pokok Kepegawaian

Peraturan Pemerintah Nomor 53 Tahun 2010 tentang Disiplin Pegawai Negeri Sipil 